Article

\title{
Identification and Analysis of RNA Editing Sites in the Chloroplast Transcripts of Aegilops tauschii L.
}

\author{
Mengxing Wang, Hui Liu, Lingqiao Ge, Guangwei Xing, Meng Wang, Song Weining * and \\ Xiaojun Nie *
}

State Key Laboratory of Crop Stress Biology in Arid Areas, College of Agronomy, Northwest Agriculture and Forestry University, Yangling 712100, Xianyang, China; machine@nwsuaf.edu.cn (M.-X.W.); m15191417214@163.com (H.L.); lqiaoge@163.com (L.G.); fire_wind_withcity@163.com (G.X.); wm2008xs@163.com (M.W.)

* Correspondence: sweining2002@yahoo.com (S.W.); small@nwsuaf.edu.cn (X.N.); Tel.: +86-029-8708-2984 (S.W.); +86-134-6884-6103 (X.N.)

Academic Editor: H. Ulrich Göringer

Received: 23 September 2016; Accepted: 20 December 2016; Published: 30 December 2016

\begin{abstract}
RNA editing is an important way to convert cytidine (C) to uridine (U) at specific sites within RNA molecules at a post-transcriptional level in the chloroplasts of higher plants. Although it has been systematically studied in many plants, little is known about RNA editing in the wheat D genome donor Aegilops tauschii L. Here, we investigated the chloroplast RNA editing of Ae. tauschii and compared it with other wheat relatives to trace the evolution of wheat. Through bioinformatics prediction, a total of 34 C-to-U editing sites were identified, 17 of which were validated using RT-PCR product sequencing. Furthermore, 60 sites were found by the RNA-Seq read mapping approach, 24 of which agreed with the prediction and six were validated experimentally. The editing sites were biased toward $\mathrm{tC}$ or $\mathrm{nCa}$ trinucleotides and 5'-pyrimidines, which were consistent with the flanking bases of editing sites of other seed plants. Furthermore, the editing events could result in the alteration of the secondary structures and topologies of the corresponding proteins, suggesting that RNA editing might impact the function of target genes. Finally, comparative analysis found some evolutionarily conserved editing sites in wheat and two species-specific sites were also obtained. This study is the first to report on RNA editing in Aegilops tauschii L, which not only sheds light on the evolution of wheat from the point of view of RNA editing, but also lays a foundation for further studies to identify the mechanisms of C-to-U alterations.
\end{abstract}

Keywords: Aegilops tauschii; chloroplast; RNA editing; Triticum

\section{Introduction}

RNA editing is a post-transcriptional process for converting cytidine $(\mathrm{C})$ to uridine $(\mathrm{U})$, or $\mathrm{U}$ to $\mathrm{C}$, at specific sites within RNA molecules to alter the identity of nucleotides between RNA and genomic DNA, serving as a mechanism to correct missense mutations of genes at the RNA level, and also to enrich genetic information [1,2]. It can act upon transcripts in the cell nucleus, cytoplasm, mitochondria, and chloroplast (cp), which has been widely documented in various organisms, including eukaryotes, prokaryotes, archaebacteria, viruses, etc. [3-5]. Since the first editing event of the land plant plastome was found in the mRNA transcript of the rpl2 gene in the maize chloroplast genome in 1991 [6], extensive RNA editing sites have been detected in a variety of higher plants, such as tobacco [7,8], Arabidopsis [9], pea [10], and tomato [11], and some of them have been validated by experiments [12]. Hornwort and fern exhibit hundreds of C-to-U as well as U-to-C editing sites [13,14]; however, in angiosperms, approximately 30 to $40 \mathrm{C}-\mathrm{U}$ editing sites are found in the chloroplasts [15]. In other land plant clades, editing frequencies vary widely, with no editing in marchantiid liverworts [16]. 
Although a few cases of editing within the noncoding regions or introns have been reported, most of the known editing events occur in exons, restoring corresponding amino acids to a more conserved direction $[17,18]$. Additionally, editing usually occurs in the second or first base of codons, resulting in the conversion of hydrophilic amino acid to hydrophobic, in most cases $[19,20]$. As an essential step of RNA maturation in plant organelles, the molecular mechanisms of RNA editing have been extensively studied [21]. It is widely accepted that PPR (pentatricopeptide repeat) proteins are the key factor to regulate RNA editing through binding to the target transcripts and then altering the RNA sequence turnover, processing, and translation [22-24].

Aegilops tauschii L., also known as Tausch's goatgrass, is an annual grass belonging to the Triticeae tribe of the Poaceae family, which is found all over the world, including in China, Central and Western Asia, the Caucasus, Eastern Europe, and America. Ae. tauschii donated the D genome of hexaploid wheat (Triticum aestivum L.) by a spontaneous hybridization of the wild diploid grass Ae. tauschii with the tetraploid wheat Triticum turgidum about 8000-10,000 years ago in the Fertile Crescent $[25,26]$, which holds promise for the underlying processes of wheat formation and evolution. Extensive studies have been conducted to reveal the roles of Ae. tauschii in the evolutionary origin of polyploid wheat from different viewpoints, such as complete genome sequencing [27], physical mapping [28], and plastome sequences [29], as well as population genetic analyses [30]. However, the RNA editing sites in Ae. tauschii have not been well understood up to now. To trace the evolutionary process of polyploid wheat from the perspective of chloroplast RNA editing, we investigated and compared the chloroplast RNA editing patterns of Ae. tauschii together with other wheat relative species in this study. Firstly, the RNA editing sites in 76 chloroplast transcripts of Ae. tauschii were identified using bioinformatics prediction, combined with the RNA-Seq read mapping approach. Then, these predicted editing sites were further validated through PCR and RT-PCR. Furthermore, the alterations of the secondary structures of these proteins were investigated to understand the potential biological functions of these editing events. Finally, the chloroplast RNA editing sites in Ae. tauschii were compared with those of common wheat, wheat A and B genome progenitors, as well as five other Poaceae species to provide information regarding the origin and evolution of chloroplast RNA editing in wheat and beyond.

\section{Materials and Methods}

\subsection{Prediction of RNA Editing Sites}

All of the 76 protein-coding genes in the plastome of Ae. tauschii (AL8/78) (GenBank Accession: KJ614412.1) were downloaded from the NCBI (National Center for Biotechnology Information) database (https: / / www.ncbi.nlm.nih.gov) according to their annotation information [29]. Potential RNA editing sites in these genes were predicted by the Predictive RNA Editor for Plants (PREP)-Cp web server (http://prep.unl.edu/cgi-bin/cp-input.pl) [31] with a cutoff value of 0.8. Bioedit [32] and Microsoft Excel tools were used to format the required input file.

\subsection{Editing Site Detection by Read Mapping and SNP (Single Nucleotide Polymorphism) Calling}

RNA-Seq data from eight tissues of Ae. tauschii (AL8/78) were downloaded from the Sequence Read Archive (SRA) database with the accession numbers of SRX209402 SRX209425 (Table S1) [27]. The RNA-Seq reads were mapped to the cp genome of Ae. tauschii (AL8/78) using the Tophat tool [33]. SNPs were called by SAMtools to detect potential changes of $C$ to $U$ in the sense-strand and $\mathrm{G}$ (guanine) to A (adenine) in the antisense-strand of the cp genome. The mapped reads were subsequently visualized in the Integrative Genomics Viewer [34]. Only the DNA:RNA mismatches that had at least $5 \%$ editing efficiency, and more than five individual read supports were kept. RNA editing efficiency was counted by edited reads divided by total mapped reads [2]. 


\subsection{Protein Structure Analysis before and after Editing}

CFSSP (Chou and Fasman Secondary Structure Prediction Server) (http:/ /www.biogem.org/tool/ chou-fasman/) [35,36] was used to analyze the protein secondary structures of amino acid sequences translated from edited and unedited RNA. Prediction of transmembrane segments before and after editing, was performed using the Phobius tool (http:/ / phobius.sbc.su.se/) [37].

\subsection{Comparative Analysis of RNA Editing Sites in Cp Protein-Coding Genes among Poaceae Species}

Previous study has been conducted to reveal the origin and evolution of RNA editing in cereal mitochondria [38]. Similarly, we compared and analyzed RNA editing in chloroplasts of Poaceae species. Firstly, the RNA editing sites in cp protein-coding genes of Ae. tauschii were compared to those of Hordeum vulgare [39], Lolium perenne [40], Oryza sativa [41], Saccharum officinarum [42], and Zea mays [17] to identify the patterns of RNA editing in Poaceae plastomes. Furthermore, all of the chloroplast protein-coding genes of Triticum urartu, Aegilops speltoides, and T. turgidum, as well as T. aestivum (Table 1) [29], were downloaded and potential RNA editing sites in these genes were predicted using the methods described above, and then the differences among these species were investigated.

Table 1. Information of complete chloroplast genome for comparative analysis of RNA editing sites in protein-coding genes among Poaceae species.

\begin{tabular}{cc}
\hline Material Name & GenBank Accession \\
\hline Ae. tauschii (AL8/78) & KJ614412.1 \\
T. urartu (PI428335) & KJ614411.1 \\
Ae. speltoides ssp. ligustica (AE918) & KJ614404.1 \\
Ae. speltoides ssp. ligustica (TA1796) & KJ614405.1 \\
Ae. speltoides ssp. speltoides (PI487232) & KJ614406.1 \\
T. turgidum ssp. dicoccoides (TA0073) & KJ614400.1 \\
T. turgidum ssp. dicoccoides (TA0060) & KJ614401.1 \\
T. turgidum ssp. dicoccoides (TA1133) & KJ614402.1 \\
T. aestivum ssp. aestivum cr Chinese Spring (CS) (TA3008) & KJ614396.1 \\
\hline
\end{tabular}

\subsection{Validation of Partial RNA Editing Sites}

Seeds of Ae. tauschii (AL8/78) were put on moistened filter paper in a dish and then cultured in a growth chamber under the condition of $20^{\circ} \mathrm{C}$ and a natural light/dark cycle. One-week-old seedlings were harvested for DNA and RNA isolation. Genomic DNA was extracted, as described previously [43]. Total RNA was isolated from the seedlings using the E.Z.N.A. ${ }^{\circledR}$ Plant RNA Kit (Omega, Norcross, GA, USA) and then treated with HiScript ${ }^{\mathrm{TM}}$ Q RT SuperMix (+gDNA wiper) (Vazyme, Nanjing, China) to remove genomic DNA and to synthesize cDNAs, according to the manufacturer's instructions.

The extracted DNA and obtained cDNAs were used as PCR templates for the validation of specific RNA editing sites, namely 18 sites of six genes, selected randomly from the prediction, as well as six sites in six genes identified by RNA-seq read mapping. In total, 11 specific primers (Table S2) were designed according to the candidate regions (Table S3). The PCR reaction $(20 \mu \mathrm{L})$ contained $10 \mu \mathrm{M}$ of each primer, $1 \times$ EsTaq Mix (Cwbiotech, Beijing, China) and up to $1000 \mathrm{ng}$ of template. The reaction proceeded through 35 cycles after an initial denaturation for $2 \mathrm{~min}$ at $94{ }^{\circ} \mathrm{C}$, and was followed by a final extension for $5 \mathrm{~min}$ at $72{ }^{\circ} \mathrm{C}$. One thermo cycle was $94{ }^{\circ} \mathrm{C}$ for $30 \mathrm{~s}$, annealing for $30 \mathrm{~s}$, and $72{ }^{\circ} \mathrm{C}$ for extension. The annealing temperature and extension time were adjusted to the Tm value of the primer pair and the length of product, respectively. The resulting products were separated by $1 \%$ agarose gel electrophoresis and were purified with a Universal DNA Purification Kit (Tiangen, Beijing, China), following the manufacturer's instructions. The homogeneous products of petL, ndhK, rpoA, rps3, ndhD, $n d h G$, and $r p o B$ were sequenced directly from both directions by Sangon Biotech Corporation (Shanghai, China). The products of $n d h B, \operatorname{atp} A$, matK, $n d h A$, and $r p o B$ were subsequently ligated into pMD18-T Vector (Takara, Shiga, Japan) and transformed into Escherichia coli DH5 $\alpha$. Two positive clones were 
selected for each fragment to sequence (both directions for $n d h B$ and only one direction for others) by Sangon Biotech Corporation. Both DNA and cDNA sequences were spliced using the ContigExpress tool implemented in Vector NTI suite 6.0 (Invitrogen, Waltham, MA, USA), and the RNA editing sites were validated by aligning cDNAs with corresponding genomic DNA sequences using the ClustalW program (http://www.ebi.ac.uk/Tools/msa/clustalw2/) [44].

\section{Results and Discussion}

\subsection{Prediction of RNA Editing Sites}

In total, 34 editing sites present in 15 chloroplast protein-coding genes (Table 2) were predicted by the PREP-Cp program in Ae. tauschii, all of which were C-to-U conversions. Among them, $n d h$ genes showed the most abundant editing sites with a total of 15 , followed by rpo genes with a value of 10 , and $y c f$ with two editing events. Furthermore, 30 out of 34 (88.24\%) editing events were observed in the second position of the codon and the rest were in the first position.

Table 2. RNA editing sites in chloroplast protein-coding genes of Ae. tauschii (AL8/78) predicted by PREP-Cp.

\begin{tabular}{|c|c|c|c|c|}
\hline Gene & $\begin{array}{l}\text { Nucleotide } \\
\text { Position }\end{array}$ & $\begin{array}{l}\text { Amino Acid } \\
\text { Position }\end{array}$ & $\begin{array}{c}\text { Codon } \\
\text { Conversion }\end{array}$ & $\begin{array}{l}\text { Amino Acid } \\
\text { Conversion }\end{array}$ \\
\hline & $473^{a}$ & 158 & $\mathrm{tCa}>\mathrm{tTa}$ & $\mathrm{S}>\mathrm{L}$ \\
\hline \multirow{2}{*}{$n d h A$} & $563^{a}$ & 188 & $\mathrm{tCa}>\mathrm{tTa}$ & $S>L$ \\
\hline & 1070 & 357 & $\mathrm{tCt}>\mathrm{tTt}$ & $\mathrm{S}>\mathrm{F}$ \\
\hline $\operatorname{atp} A$ & $1148^{a}$ & 383 & $\mathrm{tCa}>\mathrm{tTa}$ & $\mathrm{S}>\mathrm{L}$ \\
\hline atpB & 1487 & 496 & $\mathrm{tCg}>\mathrm{tTg}$ & $S>L$ \\
\hline \multirow[t]{5}{*}{ matK } & $1261^{a}$ & 421 & Cat $>$ Tat & $\mathrm{H}>\mathrm{Y}$ \\
\hline & $149^{\mathrm{a}}$ & 50 & $\mathrm{tCa}>\mathrm{tTa}$ & $\mathrm{S}>\mathrm{L}$ \\
\hline & $467^{\mathrm{a}}$ & 156 & $\mathrm{cCa}>\mathrm{cTa}$ & $\mathrm{P}>\mathrm{L}$ \\
\hline & $586^{a}$ & 196 & Cat $>$ Tat & $\mathrm{H}>\mathrm{Y}$ \\
\hline & $611^{a}$ & 204 & $\mathrm{tCa}>\mathrm{tTa}$ & $\mathrm{S}>\mathrm{L}$ \\
\hline \multirow[t]{5}{*}{$n d h B$} & $704^{a}$ & 235 & $\mathrm{tCc}>\mathrm{tTc}$ & $\mathrm{S}>\mathrm{F}$ \\
\hline & $737^{a}$ & 246 & $\mathrm{cCa}>\mathrm{cTa}$ & $\mathrm{P}>\mathrm{L}$ \\
\hline & $830^{a}$ & 277 & $\mathrm{tCa}>\mathrm{tTa}$ & $S>L$ \\
\hline & $836^{a}$ & 279 & $\mathrm{tCa}>\mathrm{tTa}$ & $S>L$ \\
\hline & $1481^{a}$ & 494 & cCa $>$ cTa & $\mathrm{P}>\mathrm{L}$ \\
\hline$n d h D$ & $878^{a}$ & 293 & $\mathrm{tCa}>\mathrm{tTa}$ & $S>L$ \\
\hline \multirow{2}{*}{$n d h F$} & 62 & 21 & $\mathrm{tCa}>\mathrm{tTa}$ & $S>L$ \\
\hline & 1487 & 496 & $\mathrm{aCg}>\mathrm{aTg}$ & $\mathrm{T}>\mathrm{M}$ \\
\hline \multirow[t]{3}{*}{ petB } & 662 & 221 & cСa>cTa & $\mathrm{P}>\mathrm{L}$ \\
\hline & 2009 & 670 & $\mathrm{cCa}>\mathrm{cTa}$ & $\mathrm{P}>\mathrm{L}$ \\
\hline & 2030 & 677 & cCa $>$ cTa & $\mathrm{P}>\mathrm{L}$ \\
\hline \multirow[t]{3}{*}{ rрос2 } & 2158 & 720 & $\mathrm{Ccc}>\mathrm{Tcc}$ & $\mathrm{P}>\mathrm{S}$ \\
\hline & 3002 & 1001 & $\mathrm{cCg}>\mathrm{cTg}$ & $\mathrm{P}>\mathrm{L}$ \\
\hline & 4031 & 1344 & $\mathrm{tCg}>\mathrm{tTg}$ & $\mathrm{S}>\mathrm{L}$ \\
\hline$r p l 2$ & 62 & 21 & $\mathrm{aCt}>\mathrm{aTt}$ & $\mathrm{T}>\mathrm{I}$ \\
\hline rpl20 & 308 & 103 & $\mathrm{tCa}>\mathrm{tTa}$ & $S>L$ \\
\hline \multirow[t]{2}{*}{ rpoA } & 1009 & 337 & $\mathrm{Ctc}>\mathrm{Ttc}$ & $\mathrm{L}>\mathrm{F}$ \\
\hline & $467^{\mathrm{a}}$ & 156 & $\mathrm{tCg}>\mathrm{tTg}$ & $\mathrm{S}>\mathrm{L}$ \\
\hline \multirow{3}{*}{$r p o B$} & $545^{a}$ & 182 & $\mathrm{tCa}>\mathrm{tTa}$ & $S>L$ \\
\hline & $560^{a}$ & 187 & $\mathrm{tCg}>\mathrm{tTg}$ & $\mathrm{S}>\mathrm{L}$ \\
\hline & $617^{b}$ & 206 & $\mathrm{cCg}>\mathrm{cTg}$ & $\mathrm{P}>\mathrm{L}$ \\
\hline rps 8 & 182 & 61 & tCa>tTa & $\mathrm{S}>\mathrm{L}$ \\
\hline \multirow{2}{*}{$y c f 3$} & 44 & 15 & $\mathrm{tCc}>\mathrm{tTc}$ & $\mathrm{S}>\mathrm{F}$ \\
\hline & 191 & 64 & $\mathrm{aCg}>\mathrm{aTg}$ & $\mathrm{T}>\mathrm{M}$ \\
\hline
\end{tabular}

Capitals in column Codon Conversion indicate target nucleotides. ${ }^{\text {a }}$ Editing sites with experimental verification.

${ }^{\mathrm{b}}$ Unedited by experimental verification. 


\subsection{Editing Site Detection Using Read Mapping and SNP Calling}

A total of 60 sites were identified as RNA editing sites by read mapping and SNP calling, 24 of which agreed with the prediction (Table 3). Among them, only 11 sites were found to be completely edited, and the remaining sites were partially edited, accounting for $81 \%$ ( 49 of 60), which was lower than the $100 \%$ value of $A$. thaliana [45]. The abundant, partially edited transcripts, in which not all of the $C$ targets had been converted to Us, might be an intermediate phase in the editing process [15] and might result in more than one protein product encoded by the same gene, suggesting that chloroplast RNA editing was a post-transcriptional process [4]. Furthermore, 20 sites were found to be localized in the intergenic region, presumably affecting $5^{\prime}$ or $3^{\prime}$ UTRs, and two were located within the intron of rps16.

It has been demonstrated that the editing sites in the chloroplasts of seed plants preferred $5^{\prime}-\mathrm{T}-\mathrm{A}-3^{\prime}$ flanking bases and/or a $5^{\prime}$-pyrimidine due to the genomic context with lower substitution rates [46-48]. Thus, we further analyzed the flanking bases of all 70 editing sites identified via the bioinformatics prediction and RNA-Seq data. Results revealed that 31.43\% (22 of 70) of sites showed a tCa bias and $81.43 \%$ (57 of 70) possessed tCn or nCa trinucleotides (Figure 1). Additionally, a $5^{\prime}$-pyrimidine was observed in 61 sites, accounting for $87.14 \%$, of which thymine accounted for $57.14 \%$ and cytosine accounted for $30.00 \%$. Furthermore, all the editing events in the protein-coding genes could result in eight types of amino acid transitions (Figure 2). Among them, 27 out of 40 editing events $(67.5 \%)$ led to a conversion from hydrophilic amino acid to hydrophobic amino acid (Figure 2, red bar), with only one changing from hydrophobic amino acid to hydrophilic amino acid $(\mathrm{P} \rightarrow \mathrm{S})$ (Figure 2, blue bar), and the remaining 12 without hydrophobicity exchanges (Figure 2, green bar). Moreover, most of the amino acid conversions affected by RNA editing were serine to leucine (17), followed by proline to leucine (11). This was most likely due to serine being encoded by $\mathrm{tCn}$ and proline by the cCn codon. The low re-mutation biased genomic context could result in the conservative (functionally similar) amino acid exchange, probably without negative effects on protein function [49].

Additionally, six silent editing sites with no impact on the encoded amino acid were also detected, including pistil-specific atpA-234 and rpl16-36, spike-specific $p s b B-414$, and rps3-30 edited in all tissues. Editing events at sites rps18-448 and $n d h F-1891$ generated stop codons, resulting in the premature termination of transcription, which only occurred in pistils with relatively low efficiency (9\%). Furthermore, editing events at $n d h B-586, n d h B-611, n d h B-704$, and $n d h B-1481$ on the sense-strand, as well as $n d h B-836, n d h B-149, n d h A-1070$, and $n d h A-563$ on the antisense-strand, were found to only occur in leaves, while rps4-305 was specifically edited in seeds. 
Table 3. Cytidine (C) to uridine (U) editing sites in chloroplast genome of Ae. tauschii (AL8/78) validated by RNA-Seq data.

\begin{tabular}{|c|c|c|c|c|c|c|c|c|c|c|c|c|c|c|c|c|c|c|c|c|c|c|c|c|c|c|c|}
\hline \multirow{2}{*}{$\begin{array}{l}\text { Genome } \\
\text { Position }\end{array}$} & \multirow{2}{*}{ Gene Position } & \multirow{2}{*}{ Codon } & \multirow{2}{*}{$\begin{array}{c}\text { Amino } \\
\text { Acid }\end{array}$} & \multicolumn{5}{|c|}{ Leaf } & \multicolumn{2}{|c|}{ Pistil } & \multicolumn{2}{|c|}{ Root } & \multicolumn{4}{|c|}{ Seed } & \multicolumn{3}{|c|}{ Sheath } & \multicolumn{4}{|c|}{ Spike } & \multicolumn{2}{|c|}{ Stamen } & \multicolumn{2}{|l|}{ Stem } \\
\hline & & & & $1^{b}$ & 2 & 3 & 4 & 5 & 1 & 1 & 2 & 3 & 4 & 1 & 2 & 3 & 1 & 2 & 3 & 4 & 1 & 2 & 3 & 1 & 1 & 2 & 3 \\
\hline \multicolumn{28}{|c|}{ Sense-strand } \\
\hline 3090 & $\sim p s b K$ & & & & & & & & 22 & & & & & & & & & & & & & & & & & & \\
\hline 3551 & $\sim p s b K$ & & & & & & & & 7 & & & & & & & & & & & & & & & & & & \\
\hline 8481 & $p s b I \sim p s b D$ & & & & & & & & 9 & & & & & & & & & & & & & & & & & & \\
\hline 11,311 & $p s b C \sim p s b Z$ & & & 21 & & 19 & 20 & & 18 & & & & & & & & & & 10 & & & & 10 & & 9 & & \\
\hline 20,093 & rpoB-467 a & $\mathrm{t} C g$ & $S>L$ & & & & & 38 & 28 & & & & & & & & 66 & 75 & 78 & 90 & & & & 72 & & & 32 \\
\hline 20,171 & rpob-545 a & tCa & $S>L$ & & & & & & 48 & & & & & & & & 70 & 86 & 88 & 78 & & & & 71 & & & \\
\hline 20,186 & rpoB-560 a & $\mathrm{tCg}$ & $S>L$ & & & & & & 57 & & & & & & & & 73 & 86 & 80 & 85 & & & & 69 & & & \\
\hline 32,404 & atpH atpF & & & & & & 18 & 18 & & & & & & 15 & & & & & & & & & & & & & \\
\hline 34,440 & atpA-234 & $\operatorname{ggC}$ & $G>G$ & & & & & & 11 & & & & & & & & & & & & & & & & & & \\
\hline 35,354 & $\operatorname{atp} A-1148^{\mathrm{a}}$ & tCa & $S>L$ & 99 & 98 & 99 & 99 & 99 & & 83 & 94 & 98 & 91 & 94 & 91 & 87 & 96 & 90 & 94 & 96 & 95 & & 94 & 71 & 93 & 95 & 94 \\
\hline 42,415 & atpA $\sim r n S-G G A$ & & & & & & & & & & & & & & & & & 14 & & & & & & & & & \\
\hline 57,960 & $y c f 4 \sim \operatorname{cem} A$ & & & 52 & 50 & 67 & 48 & 55 & 12 & & & & & & & & 37 & 42 & 27 & 31 & & & & 23 & & & 26 \\
\hline 62,758 & pet $L-56^{\mathrm{d}}$ & $\mathrm{cCa}$ & $\mathrm{P}>\mathrm{L}$ & 83 & 75 & 62 & 77 & 60 & & & & & & & & & 58 & & 36 & 30 & & & & & 83 & & \\
\hline 65,352 & rps $18-448$ & Cga & $\mathrm{R}>$ Stop & & & & & & 9 & & & & & & & & & & & & & & & & & & \\
\hline 68,447 & psbB-414 & $\mathrm{atC}$ & $\mathrm{L}>\mathrm{L}$ & & & & & & & & & & & & & & & & & & & & 17 & & & & \\
\hline 71,835 & petB-662 a & $\mathrm{cCa}$ & $\mathrm{P}>\mathrm{L}$ & 96 & 98 & 97 & 98 & 90 & & & & & & 43 & & 27 & & & & 34 & & & 66 & 58 & 26 & & 13 \\
\hline 127,814 & $n d h B-149^{\text {a }}$ & $\mathrm{tCa}$ & $S>L$ & 94 & & & & & & & & & & & & & & & & 96 & & & & & & & \\
\hline 128,251 & ndhB-586 a & Cat & $\mathrm{H}>\mathrm{Y}$ & 95 & 88 & 91 & 93 & 93 & & & & & & & & & & & & & & & & & & & \\
\hline $\begin{array}{l}\text { Genome } \\
\text { Position }\end{array}$ & Gene Position & Codon & Acid & 1 & 2 & 3 & 4 & 5 & 1 & 1 & 2 & 3 & 4 & 1 & 2 & 3 & 1 & 2 & 3 & 4 & 1 & 2 & 3 & 1 & 1 & 2 & 3 \\
\hline & e-strand & & & & & & & & & & & & & & & & & & & & & & & & & & \\
\hline 128,369 & $n d h B-704^{\text {a }}$ & $t C c$ & $\mathrm{~S}>\mathrm{F}$ & & & & 92 & & & & & & & & & & & & & & & & & & & & \\
\hline 129,858 & $n d h B-1481^{\text {a }}$ & $\mathrm{cCa}$ & $\mathrm{P}>\mathrm{L}$ & 96 & 99 & 99 & & 97 & & & & & & & & & & & & & & & & & & & \\
\hline An & nse-strand & & & & & & & & & & & & & & & & & & & & & & & & & & \\
\hline 1956 & matK-1261 a & Cat & $\mathrm{H}>\mathrm{Y}$ & 66 & 45 & 41 & 69 & 52 & 13 & & & 36 & & & & & 69 & 55 & 38 & 69 & 55 & & 50 & 36 & 61 & & 71 \\
\hline 5100 & rps16-intron & & & 19 & 17 & 22 & 23 & 22 & 89 & 54 & 51 & 50 & & 65 & & & 36 & 33 & 32 & 37 & 83 & & 83 & 60 & 66 & 70 & 60 \\
\hline 5179 & rps16-intron & & & & & & & & & 15 & 15 & 23 & & & & & & & & & & & & & & & \\
\hline 36,673 & rps14 psaB & & & 45 & 45 & 45 & 44 & 45 & & & & & & & & & 20 & & 20 & 14 & & & 19 & 23 & & & 8 \\
\hline 42,982 & $y c f 3-191^{\text {a }}$ & $\mathrm{aCg}$ & $\mathrm{T}>\mathrm{M}$ & 79 & 83 & 82 & 81 & 80 & 63 & 44 & 55 & 45 & 39 & & & 49 & 70 & 69 & 67 & 63 & 64 & & 74 & 64 & 72 & & 76 \\
\hline 43,880 & $y c f 3-44^{\text {a }}$ & $t C c$ & $\mathrm{~S}>\mathrm{F}$ & 92 & 92 & 96 & 97 & 92 & 40 & 71 & 68 & 70 & 26 & 46 & & & 70 & 70 & 69 & 82 & 42 & & 50 & 43 & 69 & 77 & 74 \\
\hline 44,727 & $y c f 3 \sim \mathrm{rps} 4$ & & & 78 & 68 & 71 & 75 & 65 & 38 & & & & & 41 & & & 35 & 29 & 35 & 19 & & & & & 20 & 21 & \\
\hline 44,868 & ycf3 rps4 & & & & & & & & 11 & & & & & & & & & & & & & & & & & & \\
\hline 45,244 & rps4-305 & $\mathrm{tCa}$ & $S>L$ & & & & & & & & & & & 20 & & & & & & & & & & & & & \\
\hline 49,393 & $n d h K-125^{\mathrm{d}}$ & $\mathrm{cCa}$ & $\mathrm{P}>\mathrm{L}$ & 99 & 98 & 99 & 99 & 99 & + & & & 70 & + & 71 & & & 96 & 97 & 94 & 94 & + & & 93 & 89 & 95 & & 89 \\
\hline 49,858 & $n d h C-13$ & $\mathrm{Cac}$ & $\mathrm{H}>\mathrm{Y}$ & 98 & 98 & 98 & 99 & 99 & 75 & 86 & 83 & 63 & 63 & 86 & & & 86 & 92 & 85 & 91 & & & 56 & 80 & 83 & & 63 \\
\hline
\end{tabular}


Table 3. Cont

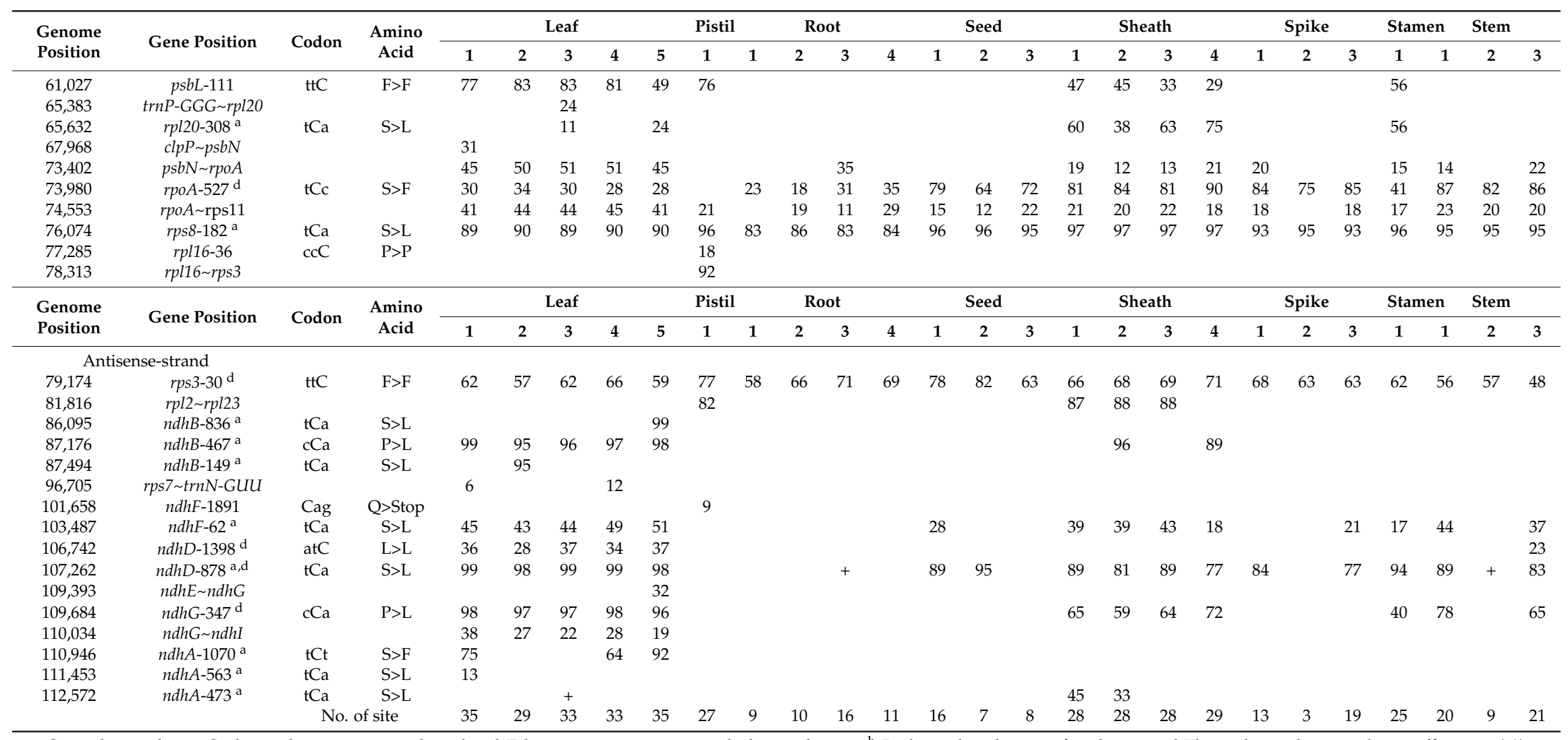

Capitals in column Codon indicate target nucleotides. ${ }^{a}$ Editing sites consistent with the prediction. ${ }^{b}$ Biological replicates of each tissue. ${ }^{\mathrm{c}}$ This value indicates editing efficiency $(\%)$.

$\mathrm{d}$ Editing sites validated by direct sequencing of PCR products. +, Complete editing (editing efficiency, 100\%). Blank, no editing/not yet determined. 


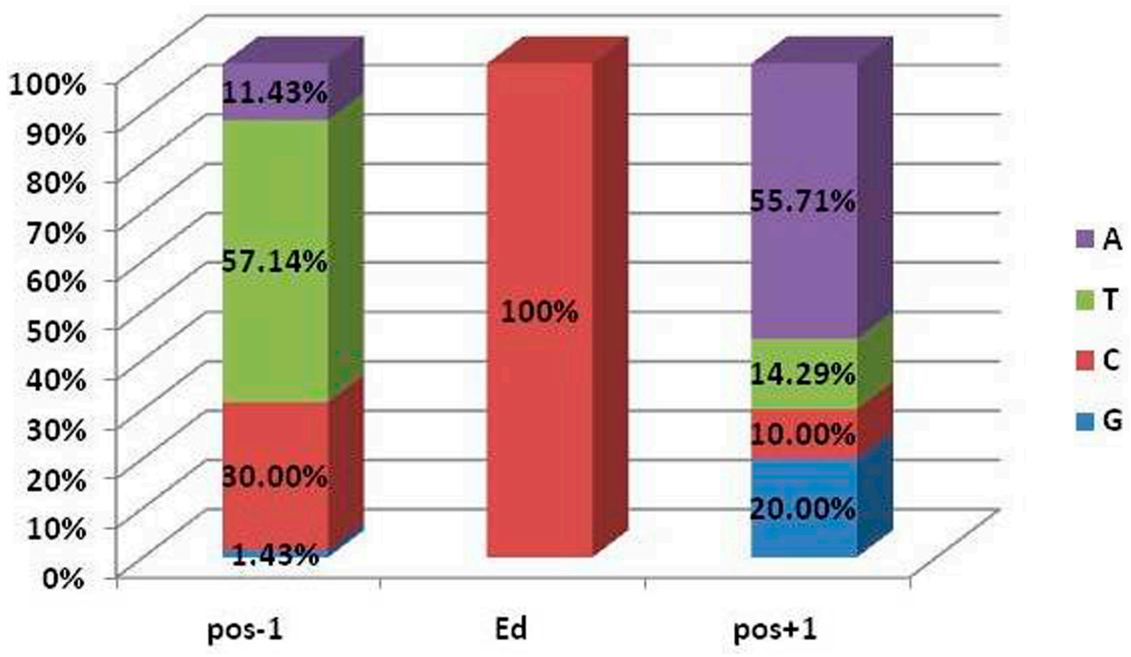

Figure 1. Nucleotide context of editing sites in Ae. tauschii (AL8/78). pos -1 and pos +1 indicate the direct upstream and downstream nucleotide of the edited sites $(\mathrm{Ed})$.

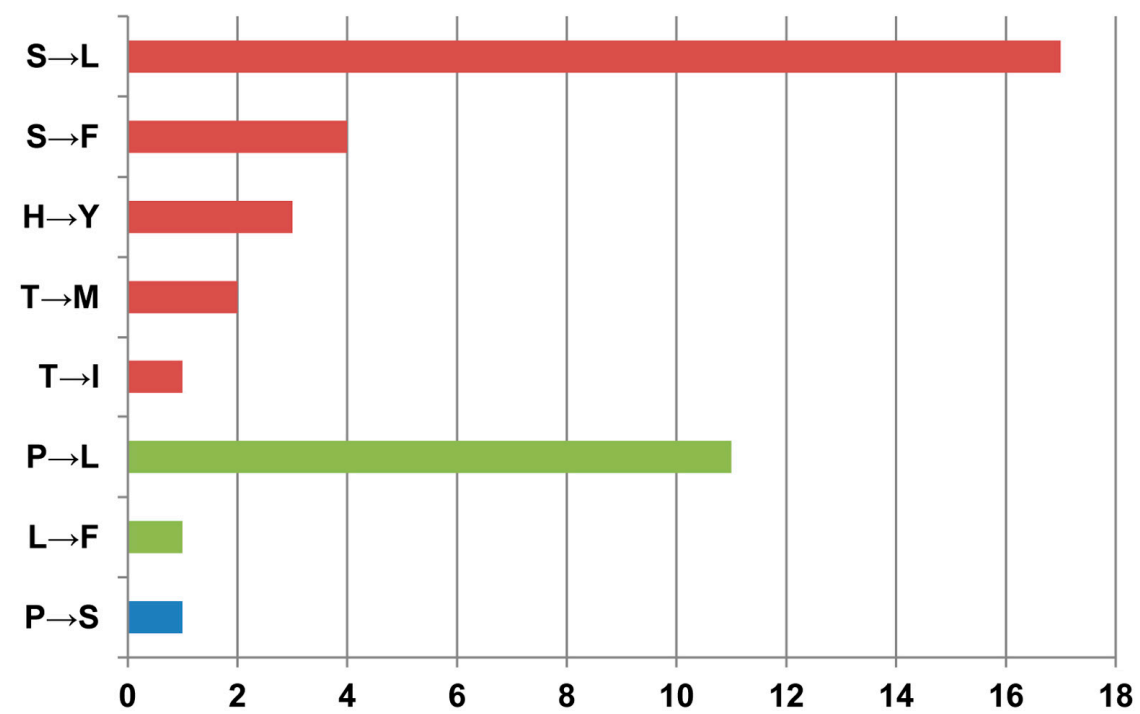

Figure 2. Types and quantities of amino acid exchanges arising from chloroplast RNA editing in Ae. tauschii (AL8/78). The red bars represent a conversion of amino acid from hydrophilic to hydrophobic, while blue is for the opposite direction and green is for no hydrophobicity exchanges.

\subsection{Validation of the RNA Editing Sites by RT-PCR Analysis}

To validate the predicted RNA editing sites, 24 sites of 11 genes were randomly selected for PCR and RT-PCR analyses. By comparing CDNAs with genomic sequences, 23 sites in 11 genes were proven to be true (approximately 95.83\%). Only rpoB-617 was not validated, as nucleotide $\mathrm{C}$ was present in both the mRNA and genomic DNA (Figure S1). In addition to false positives resulting from the bioinformatics prediction, one possible explanation was that rpoB-617 was edited in a tissue- or stage-specific manner, or modulated under different environmental conditions, which were not included in current study.

Generally, there are three methods to identify RNA editing sites, namely bioinformatics prediction and RNA-Seq, as well as molecular cloning. Molecular cloning is a common, widely used and accurate method to identify RNA editing in different species. Kugita et al. [50] verified a total of 509 C-to-U and 433 U-to-C conversions in hornwort chloroplasts and showed that RNA editing in hornwort chloroplasts made more than half the genes function; Jiang et al. [51] identified 54 editing sites in 
the cotton chloroplast genome, which was the highest editing frequency reported in angiosperms. However, this method requires a series of time-consuming and tedious experimental procedures, making it not suitable for genome-wide identification. In light of the evolutionary conservation, bioinformatics prediction tools have been developed to identify RNA editing, such as PREP-Cp and CURE (Cytidine to Uridine Recognizing Editor) [52]. In the cp genome of Cycas taitungensis, 85 editing sites were found in 25 transcripts using a combination of prediction by CURE and experimental determination [53]. In coconut cpDNA, RT-PCR analysis confirmed editing at 64 of the 83 PREP-Cp predicted RNA editing sites out of 27 genes [54]. With the advent of high-throughput sequencing, RNA-Seq technology provides an opportunity to investigate RNA editing sites at the transcriptome level. By read mapping and SNP calling, SNPs that emerged repeatedly and existed stable could be interpreted as edited sites. It has been gradually used to identify RNA editing on a large scale [2,55]. However, edited targets can be easily neglected, or SNPs can be falsely interpreted as true edited targets using this method [55]. Thus, to efficiently and accurately identify RNA editing sites in Aegilops tauschii L. chloroplasts, we performed identification through a combination of these three methods, which provide a systematic and comprehensive RNA editing profile of the transcriptome of Aegilops tauschii L. chloroplasts.

\subsection{Impact of RNA Editing on Protein Structure}

To preliminarily understand the biological functions of RNA editing, the secondary structures of these proteins, encoded by 15 genes with editing events, were analyzed using CFSSP and Phobius tools. Results showed that $p e t B, r p o A$, and $r p s 8$ possessed the same secondary structures, before and after editing, while editing events of the remaining 12 genes could alter the composition of the secondary structures around the editing sites (Table S4). More than half of the edited genes preferred to form new a $\alpha$-helix and $\beta$-sheet, and also more than half of them underwent a decrease of turn structures at up- and down-stream regions around the editing codon (Table S5).

In the cp genome of Chlamydomonas reinhardtii, no editing was observed at position 204 of the pet $B$ gene encoding a cytochrome $b_{6}$ subunit after introducing a proline residue in place of a leucine residue [56]. This gene modification led to a defective assembly of cytochrome $b_{6} f$ complexes, consistent with a block in the photosynthetic electron transfer so that the transformants displayed non-phototrophic phenotypes. The 204 position of petB in C. reinhardtii corresponded to the petB-662 in Ae. tauschii (AL8/78), which was in the proline codon CCA at the DNA level and was subsequently edited to the leucine codon CTA at the RNA level. Although the editing event at petB-662 had no impact on the hydrophobicity of the amino acids, the composition of the secondary structures or the number of transmembrane structures, the transmembrane region at codons 201 to 220 expanded to the $\mathrm{C}$ terminal of the protein (Figure 3A). We thus speculated that the editing event at petB-662 contributed to maintaining the functional activity of cytochrome $\mathrm{b}_{6} \mathrm{f}$ in Ae. tauschii.

There was no change in the number of transmembrane structures of $n d h A$, before and after editing, which encoded NADH dehydrogenase subunit A. Nevertheless, a contraction in the region of codons 296 to 323 was observed and the transmembrane region at codons 335 to 353 shifted to the $C$ terminal (Figure 3B). The edited codons also restored universally conserved amino acids in the $n d h A$-encoded peptides of other chloroplast species, as was found in maize [57]. In addition, $n d h B$, with all sites edited, revealed a new transmembrane region at codons 449 to 510 (Figure 3C). NdhB editing site III was reported to remain unedited in the non-photosynthetic mutants of tobacco, as well as during the etiolated stage of the seedling development of maize, whereas it was fully edited in plants with an intact photosynthetic apparatus, indicating that the editing events in $n d h B$ of Ae. tauschii might occur with a similar developmental stage-dependent manner, suggesting an unexpected link between $n d h B$ editing and photosynthesis and light-induced chloroplast development [58]. 


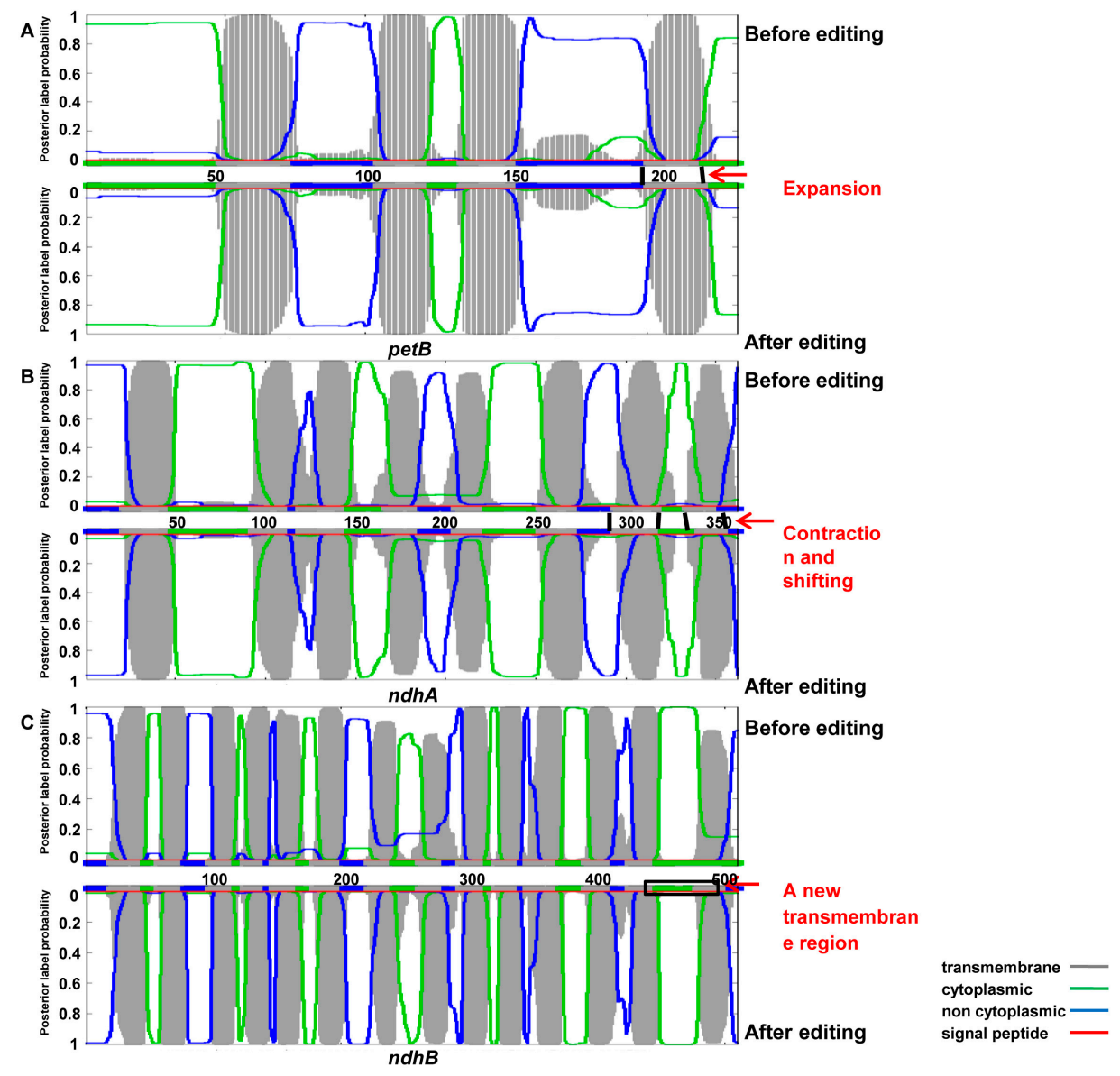

Figure 3. Transmembrane topology of petB, $n d h A$ and $n d h B$ before and after editing. (A) The transmembrane region of pet $B$ expanded to the $C$ terminal of the protein after editing; (B) The transmembrane region of $n d h A$ displayed a contraction and shift after editing; (C) NdhB showed a larger transmembrane region after editing.

\subsection{Comparative Analysis of Chloroplast RNA Editing Sites among Poaceae Species}

A total of 31 conserved RNA editing sites in 15 chloroplast protein-coding genes were systematically compared in Ae. tauschii, H. vulgare, L. perenne, O. sativa, S. officinarum, and Z. mays, 14 sites of which were found to be fully or partially edited (Table 4), establishing an evolutionarily conserved feature among these six species. No editing events occurred at $n d h A-1, n d h K-1, r p l 2-1$ and rps14-1, and the absence of edited rpl2-1 was specific to Ae. tauschii. NdhK-1 was not edited in Ae. tauschii, and nucleotide $C$ was present at the genomic DNA level. For the other three sites, nucleotide $T$ already existed at the genomic DNA level. These sites had probably re-mutated to $\mathrm{T}$ at the DNA level to remedy detrimental genomic mutations that occurred after the water-to-land transition of land plants [59]. In terms of $n d h B-1, n d h B-5$ and $n d h B-8, A e$. tauschii, H. vulgare, L. perenne and O. sativa shared edited $n d h B-5$ and $n d h B-8$, whereas $n d h B-1$ was only edited in Triticeae crops, suggesting that patterns of RNA editing were in accordance with the phylogenetic relationship (Figure S2) and there was a specific evolutionary force to drive the RNA editing events in these species. 
Table 4. Comparative analysis of RNA editing sites in chloroplast genes among six Poaceae species.

\begin{tabular}{|c|c|c|c|c|c|c|c|c|c|c|}
\hline Gene & Site & $\begin{array}{l}\text { Codon } \\
\text { Position }\end{array}$ & $\begin{array}{l}\text { Edited } \\
\text { Codon }\end{array}$ & $\begin{array}{c}\text { Amino } \\
\text { Acid } \\
\text { Conversion }\end{array}$ & $\begin{array}{c}\text { Ae. } \\
\text { tauschii }\end{array}$ & $\begin{array}{c}\text { H. } \\
\text { vulgare }\end{array}$ & $\begin{array}{c}\text { L. } \\
\text { perenne }\end{array}$ & $\begin{array}{c}O . \\
\text { sativa }\end{array}$ & $\begin{array}{c}\text { S. } \\
\text { officinarum }\end{array}$ & $\begin{array}{c}\mathrm{Z} . \\
\text { mays }\end{array}$ \\
\hline \multirow[t]{2}{*}{ matK } & 1 & $420(421)$ & Cat & $\mathrm{H} \rightarrow \mathrm{Y}$ & + & + & $+{ }^{a}$ & + & & \\
\hline & 1 & 156 & $\mathrm{tCa}$ & $\mathrm{S} \rightarrow \mathrm{L}$ & + & + & $+{ }^{a}$ & $++^{a}$ & + & + \\
\hline \multirow{3}{*}{$r p o B$} & 2 & 182 & $\mathrm{tCa}$ & $\mathrm{S} \rightarrow \mathrm{L}$ & + & + & $+{ }^{a}$ & $+{ }^{a}$ & + & + \\
\hline & 3 & 187 & $\mathrm{tCg}$ & $\mathrm{S} \rightarrow \mathrm{L}$ & + & + & $++^{a}$ & $\begin{array}{l}+{ }^{\mathrm{a}} \\
\mathrm{uCa}\end{array}$ & + & + \\
\hline & 4 & 206 & $\mathrm{cCg}$ & $\mathrm{P} \rightarrow \mathrm{L}$ & + & - & - & - & - & + \\
\hline rps14 & 1 & 27 & $\mathrm{tCa}$ & $\mathrm{S} \rightarrow \mathrm{L}$ & $(-)$ & & $(-)$ & + & $++^{a}$ & + \\
\hline $\operatorname{atp} A$ & 1 & 383 & $\mathrm{tCa}$ & $\mathrm{S} \rightarrow \mathrm{L}$ & + & & + & + & + & + \\
\hline \multirow{2}{*}{$y c f 3$} & 1 & 15 & $\mathrm{tCc}$ & $\mathrm{S} \rightarrow \mathrm{F}$ & + & & + & $(-)$ & - & + \\
\hline & 2 & $62(64)$ & $\mathrm{aCg}$ & $\mathrm{T} \rightarrow \mathrm{M}$ & + & & + & $+{ }^{a}$ & + & $++^{a}$ \\
\hline$n d h G$ & 1 & 116 & $\mathrm{cCa}$ & $\mathrm{P} \rightarrow \mathrm{L}$ & $++^{a}$ & & + & + & & $(-)$ \\
\hline rpl20 & 1 & 103 & $\mathrm{tCa}$ & $\mathrm{S} \rightarrow \mathrm{L}$ & + & & $+{ }^{a}$ & $(-)$ & $t^{\mathrm{a}}$ & + \\
\hline$p s b L$ & 1 & 37 & $\mathrm{ttC}$ & $\mathrm{F} \rightarrow \mathrm{F}$ & $++^{a}$ & & $+^{a}$ & $(-)$ & & \\
\hline$r p s 8$ & 1 & 61 & $\mathrm{tCa}$ & $\mathrm{S} \rightarrow \mathrm{L}$ & + & & + & + & + & + \\
\hline \multirow[t]{5}{*}{ rpl2 } & 1 & 1 & $\mathrm{aCg}$ & $\mathrm{T} \rightarrow \mathrm{M}$ & $(-)$ & + & $++^{a}$ & $++^{a}$ & $t^{\mathrm{a}}$ & + \\
\hline & 1 & 50 & $\mathrm{tCa}$ & $\mathrm{S} \rightarrow \mathrm{L}$ & + & + & + & $(-)$ & $(-)$ & $(-)$ \\
\hline & 2 & 156 & $\mathrm{cCa}$ & $\mathrm{P} \rightarrow \mathrm{L}$ & + & + & + & + & + & + \\
\hline & 3 & 196 & Cat & $\mathrm{H} \rightarrow \mathrm{Y}$ & + & + & + & + & + & + \\
\hline & 4 & 204 & $\mathrm{tCa}$ & $\mathrm{S} \rightarrow \mathrm{L}$ & + & + & + & $++^{a}$ & + & + \\
\hline \multirow[t]{5}{*}{$n d h B$} & 5 & 235 & $\mathrm{tCc}$ & $\mathrm{S} \rightarrow \mathrm{F}$ & + & + & + & + & $(-)$ & $(-)$ \\
\hline & 6 & 246 & $\mathrm{cCa}$ & $\mathrm{P} \rightarrow \mathrm{L}$ & + & + & + & + & + & + \\
\hline & 7 & 277 & $\mathrm{tCa}$ & $\mathrm{S} \rightarrow \mathrm{L}$ & + & + & + & + & + & + \\
\hline & 8 & 279 & $\mathrm{tCa}$ & $\mathrm{S} \rightarrow \mathrm{L}$ & + & + & + & + & $(-)$ & $(-)$ \\
\hline & 9 & 494 & $\mathrm{cCa}$ & $\mathrm{P} \rightarrow \mathrm{L}$ & + & + & + & $++^{a}$ & + & + \\
\hline$n d h F$ & 1 & 21 & $\mathrm{tCa}$ & $\mathrm{S} \rightarrow \mathrm{L}$ & + & & + & + & $++^{a}$ & + \\
\hline \multirow[t]{2}{*}{$n d h D$} & 1 & 295 (293) & $\mathrm{tCa}$ & $\mathrm{S} \rightarrow \mathrm{L}$ & + & + & $++^{a}$ & + & + & + \\
\hline & 1 & 17 & $\mathrm{tCa}$ & $\mathrm{S} \rightarrow \mathrm{L}$ & $(-)$ & + & + & $(-)$ & + & + \\
\hline \multirow{3}{*}{$n d h A$} & 2 & 158 & $\mathrm{tCa}$ & $\mathrm{S} \rightarrow \mathrm{L}$ & + & + & + & + & + & + \\
\hline & 3 & 188 & $\mathrm{tCa}$ & $\mathrm{S} \rightarrow \mathrm{L}$ & + & + & + & + & + & + \\
\hline & 4 & 357 & $\mathrm{tCc}$ & $\mathrm{S} \rightarrow \mathrm{F}$ & + & + & $(-)$ & + & + & + \\
\hline \multirow{2}{*}{$n d h K$} & 1 & 2 & $\mathrm{gtC}$ & $\mathrm{V} \rightarrow \mathrm{V}$ & - & & + & & & \\
\hline & 2 & $43(42)$ & $\mathrm{cCa}$ & $\mathrm{P} \rightarrow \mathrm{L}$ & + & & + & & & \\
\hline
\end{tabular}

Capitals in column Edited Codon indicate target nucleotides. "+", complete editing; "-", no editing and C encoded in DNA; " $(-)$ ", no editing and T encoded in DNA; "+ ${ }^{a}$ ", partial editing; Blank, no information available/not yet determined. Ae. tauschii, Aegilops tauschii L. H. vulgare, Hordeum vulgare L. L. perenne, Lolium perenne L. O. sativa, Oryza sativa L. S. officinarum, Saccharum officinarum L. Z. mays, Zea mays L.

Furthermore, to trace the evolution information of polyploid wheat from the chloroplast RNA editing point of view, we investigated and compared the chloroplast RNA editing patterns between Ae. tauschii and other wheat relatives including T. urartu, Ae. speltoides and T. turgidum. In total, 35 editing sites were detected in Ae. speltoides, T. turgidum, and T. aestivum, while only 33 sites were found in T. urartu (Tables S6-S9). Moreover, common wheat and its genome donors shared the 33 sites in 15 protein-coding genes of T. urartu (Figure 4), indicating that a highly conserved characteristic of RNA editing was present during the evolution of common wheat. It is worth noting that $a t p B-35$ and $n d h B-737$ were edited in Ae. speltoides and T. turgidum compared to T. urartu (Figure 4A). As atpB-35 and $n d h B-737$ in T. urartu, as well as atpB-35 in Ae. tauschii, were not edited, the encoded T in the DNA level might be a result of re-mutation to repair the deficient transcripts that arose from mutations as described previously. If we posited that editing sites remained stable when the genome progenitors evolved to common wheat, undergoing the natural cross and chromosome doubling, atpB-35 and $n d h B-737$ of $T$. turgidum might come from Ae. speltoides. As predicted, the editing event at atpB-35 was not observed in Ae. tauschii but occurred in T. aestivum (Figure 4B,C), suggesting that atpB-35 of T. aestivum came from T. turgidum and originated from Ae. speltoides. However, the editing event at $n d h B-737$ also occurred in Ae. tauschii. Thus, further study is needed to reveal the origin of $n d h B-737$ in common wheat. 


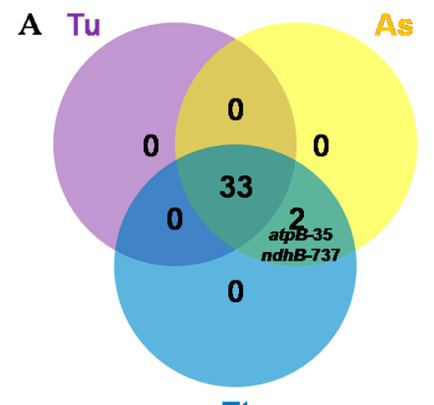

Tt
B $\mathrm{Tt}$

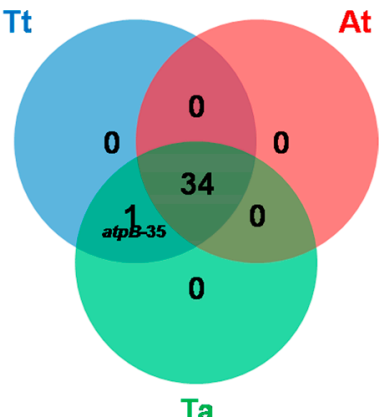

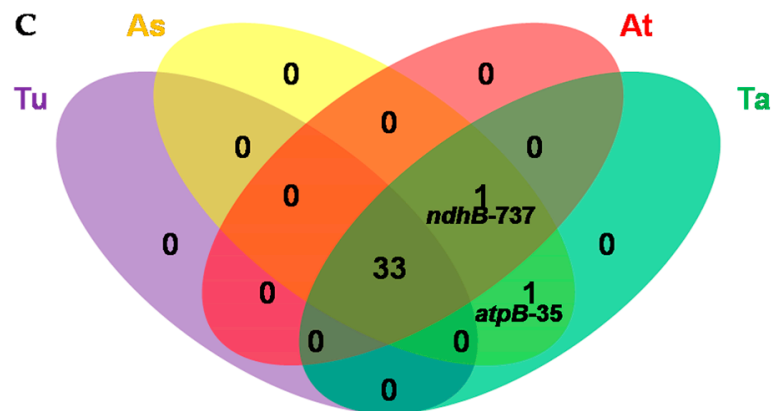

Figure 4. Comparison of RNA editing sites in chloroplast genes of T. aestivum and its genome donors. (A) Comparison among T. urartu, Ae. speltoides and T. turgidum; (B) Comparison among T. turgidum, Ae. tauschii and T. aestivum; (C) Comparison among T. urartu, Ae. speltoides, Ae. tauschii and T. aestivum. Tu indicates T. urartu (PI428335); As indicates Ae. speltoides (AE918, TA1796 and PI487232); At indicates Ae. tauschii (AL8/78); Tt indicates T. turgidum ssp. dicoccoides (TA0073, TA0060 and TA1133); and Ta indicates T. aestivum cv CS (TA3008). T. urartu, Triticum urartu L. Ae. speltoides, Aegilops speltoides L. T. turgidum, Triticum turgidum L. Ae. tauschii, Aegilops tauschii L. T. aestivum, Triticum aestivum L.

\section{Conclusions}

Here, we identified the RNA editing sites in the Ae. tauschii chloroplast genome through bioinformatics prediction, combined with RNA-Seq mapping and molecular cloning. A total of 34 editing sites in 15 protein-coding genes were predicted by PREP-Cp, of which 23 sites in 12 genes were validated by RNA-Seq mapping and 17 sites in six genes by molecular cloning. Additionally, RNA-Seq mapping detected 60 sites, seven of which were confirmed experimentally. Ae. tauschii shared similar patterns and features of RNA editing with other land plants and editing events could result in the alteration of the secondary structures of the encoded protein, which might have an impact on biological functions. Finally, comparative analysis was performed to identify the evolutionarily conserved or species-specific sites. Two sites, including atpB-35 and $n d h B-737$, were found to underlie some origin and evolutionary information of common wheat. This study, for the first time, reported on RNA editing in Aegilops tauschii L. and compared the RNA editing pattern among wheat relative species, which not only shed light on the evolution of wheat from the point of view of RNA editing, but also lay the foundation for further studies to identify the mechanisms of RNA editing in wheat and beyond.

Supplementary Materials: The following are available online at www.mdpi.com/2073-4425/8/1/13/s1, Figure S1: RNA editing sites confirmed experimentally, except $r p o B-617$ which was not edited. Arrow points to the editing site; Figure S2: The phylogeny of the compared six Poaceae species, Ae. tauschii, H. vulgare, L. perenne, O. sativa, S. officinarum and Z. mays. The phylogenetic tree of the compared six Poaceae species was reconstructed using maximum likelihood (ML) based on the RNA editing sites' composition; Table S1: Information of RNA-Seq data of Ae. tauschii (AL8/78); Table S2: Primer information used in this study; Table S3: RNA editing sites validated by each primer pair; Table S4: Quantity of protein secondary structures before and after editing; Table S5: Conversion of protein secondary structure before and after editing; Table S6: RNA editing sites in chloroplast genes of T. aestivum cv CS (TA3008) predicted by PREP-Cp; Table S7: RNA editing sites in chloroplast genes of 
T. urartu (PI428335) predicted by PREP-Cp; Table S8: RNA editing sites in chloroplast genes of Ae. speltoides (AE918, TA1796 and PI487232) predicted by PREP-Cp; Table S9: RNA editing sites in chloroplast genes of T. turgidum ssp. dicoccoides (TA0073, TA0060 and TA1133) predicted by PREP-Cp.

Acknowledgments: We thank Le Wang for good advice and technical support. This work was supported by the National Natural Science Foundation of China (Grant No. 31401373 and 31561143005), and partially supported by the Open Project of the State Key Laboratory of Crop Stress Biology in Arid Areas, Northwest Agriculture and Forestry University (Grant No. CSBAA2014002).

Author Contributions: Xiaojun Nie conceived and designed the experiments. Hui Liu and Lingqiao Ge performed the experiments. Mengxing Wang, Guangwei Xing and Meng Wang analyzed the data. Mengxing Wang and Xiaojun Nie wrote the paper. Song Weining contributed reagents/materials/analysis tools. Xiaojun Nie and Song Weining supervised the entire study.

Conflicts of Interest: The authors declare no conflicts of interest. The funding sponsors had no role in the design of the study; in the collection, analyses, or interpretation of data; in the writing of the manuscript, and in the decision to publish the results.

\section{References}

1. Wang, C.; Xu, J.-R.; Liu, H. A-to-I RNA editing independent of adars in filamentous fungi. RNA Biol. 2016, 13, 940-945. [CrossRef] [PubMed]

2. Wang, W.; Zhang, W.; Wu, Y.; Maliga, P.; Messing, J. RNA editing in chloroplasts of Spirodela polyrhiza, an aquatic monocotelydonous species. PLOS ONE 2015, 10, e0140285. [CrossRef] [PubMed]

3. Brennicke, A.; Marchfelder, A.; Binder, S. RNA editing. FEMS Microbiol. Rev. 1999, 23, 297-316. [CrossRef] [PubMed]

4. Hanson, M.R.; Sutton, C.; Luis, B. Plant organelle gene expression: Altered by RNA editing. Trends Plant Sci. 1996, 1, 57-64. [CrossRef]

5. Liu, H.; Wang, Q.; He, Y.; Chen, L.; Hao, C.; Jiang, C.; Li, Y.; Dai, Y.; Kang, Z.; Xu, J.-R. Genome-wide A-to-I RNA editing in fungi independent of ADAR enzymes. Genome Res. 2016, 26, 499-509. [CrossRef] [PubMed]

6. Hoch, B.; Maier, R.M.; Appel, K.; Igloi, G.L.; Kossel, H. Editing of a chloroplast mRNA by creation of an initiation codon. Nature 1991, 353, 178-180. [CrossRef] [PubMed]

7. Hirose, T.; Kusumegi, T.; Tsudzuki, T.; Sugiura, M. RNA editing sites in tobacco chloroplast transcripts: Editing as a possible regulator of chloroplast RNA polymerase activity. Mol. Gen. Genet. MGG 1999, 262, 462-467. [CrossRef] [PubMed]

8. Sasaki, T.; Yukawa, Y.; Miyamoto, T.; Obokata, J.; Sugiura, M. Identification of RNA editing sites in chloroplast transcripts from the maternal and paternal progenitors of tobacco (Nicotiana tabacum): Comparative analysis shows the involvement of distinct trans-factors for ndhB editing. Mol. Biol. Evol. 2003, 20, 1028-1035. [CrossRef] [PubMed]

9. Lutz, K.A.; Maliga, P. Lack of conservation of editing sites in mRNAs that encode subunits of the NAD(P)H dehydrogenase complex in plastids and mitochondria of Arabidopsis thaliana. Curr. Genet. 2001, 40, 214-219. [CrossRef] [PubMed]

10. Inada, M.; Sasaki, T.; Yukawa, M.; Tsudzuki, T.; Sugiura, M. A systematic search for RNA editing sites in pea chloroplasts: An editing event causes diversification from the evolutionarily conserved amino acid sequence. Plant Cell Physiol. 2004, 45, 1615-1622. [CrossRef] [PubMed]

11. Kahlau, S.; Aspinall, S.; Gray, J.C.; Bock, R. Sequence of the tomato chloroplast DNA and evolutionary comparison of solanaceous plastid genomes. J. Mol. Evol. 2006, 63, 194-207. [CrossRef] [PubMed]

12. Sasaki, T.; Yukawa, Y.; Wakasugi, T.; Yamada, K.; Sugiura, M. A simple in vitro RNA editing assay for chloroplast transcripts using fluorescent dideoxynucleotides: Distinct types of sequence elements required for editing of NDH transcripts. Plant J. 2006, 47, 802-810. [CrossRef] [PubMed]

13. Duff, R.J.; Moore, F.B.-G. Pervasive RNA editing among hornwort rbcL transcripts except leiosporoceros. J. Mol. Evol. 2005, 61, 571-578. [CrossRef] [PubMed]

14. Wolf, P.G.; Rowe, C.A.; Hasebe, M. High levels of RNA editing in a vascular plant chloroplast genome: Analysis of transcripts from the fern Adiantum capillus-veneris. Gene 2004, 339, 89-97. [CrossRef] [PubMed]

15. Stern, D.B.; Goldschmidt-Clermont, M.; Hanson, M.R. Chloroplast RNA metabolism. Annu. Rev. Plant Biol. 2010, 61, 125-155. [CrossRef] [PubMed]

16. Freyer, R.; Kiefer-Meyer, M.-C.; Kössel, H. Occurrence of plastid RNA editing in all major lineages of land plants. Proc. Natl. Acad. Sci. USA 1997, 94, 6285-6290. [CrossRef] [PubMed] 
17. Maier, R.M.; Neckermann, K.; Igloi, G.L.; Kössel, H. Complete sequence of the maize chloroplast genome: Gene content, hotspots of divergence and fine tuning of genetic information by transcript editing. J. Mol. Biol. 1995, 251, 614-628. [CrossRef] [PubMed]

18. Tsudzuki, T.; Wakasugi, T.; Sugiura, M. Comparative analysis of RNA editing sites in higher plant chloroplasts. J. Mol. Evol. 2001, 53, 327-332. [CrossRef] [PubMed]

19. Shikanai, T. RNA editing in plant organelles: Machinery, physiological function and evolution. Cell. Mol. Life Sci. CMLS 2006, 63, 698-708. [CrossRef] [PubMed]

20. Smith, H.C.; Gott, J.M.; Hanson, M.R. A guide to RNA editing. RNA 1997, 3, 1105-1123. [PubMed]

21. Barkan, A.; Small, I. Pentatricopeptide repeat proteins in plants. Annu. Rev. Plant Biol. 2014, 65, 415-442. [CrossRef] [PubMed]

22. Kotera, E.; Tasaka, M.; Shikanai, T. A pentatricopeptide repeat protein is essential for RNA editing in chloroplasts. Nature 2005, 433, 326-330. [CrossRef] [PubMed]

23. Takenaka, M.; Zehrmann, A.; Verbitskiy, D.; Härtel, B.; Brennicke, A. RNA editing in plants and its evolution. Annu. Rev. Genet. 2013, 47, 335-352. [CrossRef] [PubMed]

24. Zehrmann, A.; Verbitskiy, D.; Härtel, B.; Brennicke, A.; Takenaka, M. RNA editing competence of trans-factor MEF1 is modulated by ecotype-specific differences but requires the DYW domain. FEBS Lett. 2010, 584, 4181-4186. [CrossRef] [PubMed]

25. Dubcovsky, J.; Dvorak, J. Genome plasticity a key factor in the success of polyploid wheat under domestication. Science 2007, 316, 1862-1866. [CrossRef] [PubMed]

26. Salamini, F.; Ozkan, H.; Brandolini, A.; Schafer-Pregl, R.; Martin, W. Genetics and geography of wild cereal domestication in the near east. Nat. Rev. Genet. 2002, 3, 429-441. [PubMed]

27. Jia, J.; Zhao, S.; Kong, X.; Li, Y.; Zhao, G.; He, W.; Appels, R.; Pfeifer, M.; Tao, Y.; Zhang, X.; et al. Aegilops tauschii draft genome sequence reveals a gene repertoire for wheat adaptation. Nature 2013, 496, 91-95. [CrossRef]

28. Luo, M.-C.; Gu, Y.Q.; You, F.M.; Deal, K.R.; Ma, Y.; Hu, Y.; Huo, N.; Wang, Y.; Wang, J.; Chen, S.; et al. A 4-gigabase physical map unlocks the structure and evolution of the complex genome of Aegilops tauschii, the wheat D-genome progenitor. Proc. Natl. Acad. Sci. USA 2013, 110, 7940-7945.

29. Gornicki, P.; Zhu, H.; Wang, J.; Challa, G.S.; Zhang, Z.; Gill, B.S.; Li, W. The chloroplast view of the evolution of polyploid wheat. New Phytol. 2014, 204, 704-714.

30. Wang, J.; Luo, M.-C.; Chen, Z.; You, F.M.; Wei, Y.; Zheng, Y.; Dvorak, J. Aegilops tauschii single nucleotide polymorphisms shed light on the origins of wheat D-genome genetic diversity and pinpoint the geographic origin of hexaploid wheat. New Phytol. 2013, 198, 925-937. [CrossRef] [PubMed]

31. Mower, J.P. The PREP suite: Predictive rna editors for plant mitochondrial genes, chloroplast genes and user-defined alignments. Nucleic Acids Res. 2009, 37, W253-W259. [CrossRef] [PubMed]

32. Hall, T.A. Bioedit: A user-friendly biological sequence alignment editor and analysis program for Windows 95/98/NT. Nucleic Acids Symp. Ser. 1999, 41, 95-98.

33. Trapnell, C.; Pachter, L.; Salzberg, S.L. Tophat: Discovering splice junctions with RNA-seq. Bioinformatics 2009, 25, 1105-1111. [CrossRef] [PubMed]

34. Thorvaldsdóttir, H.; Robinson, J.T.; Mesirov, J.P. Integrative Genomics Viewer (IGV): High-performance genomics data visualization and exploration. Brief. Bioinform. 2013, 14, 178-192. [CrossRef] [PubMed]

35. Chou, P.Y.; Fasman, G.D. Conformational parameters for amino acids in helical, $\beta$-sheet, and random coil regions calculated from proteins. Biochemistry 1974, 13, 211-222. [CrossRef] [PubMed]

36. Chou, P.Y.; Fasman, G.D. Prediction of protein conformation. Biochemistry 1974, 13, 222-245. [CrossRef] [PubMed]

37. Käll, L.; Krogh, A.; Sonnhammer, E.L.L. A combined transmembrane topology and signal peptide prediction method. J. Mol. Biol. 2004, 338, 1027-1036. [CrossRef] [PubMed]

38. Tsunewaki, K.; Matsuoka, Y.; Yamazaki, Y.; Ogihara, Y. Evolutionary dynamics of wheat mitochondrial gene structure with special remarks on the origin and effects of rna editing in cereals. Genes Genet. Syst. 2008, 83, 301-320. [CrossRef] [PubMed]

39. Middleton, C.P.; Senerchia, N.; Stein, N.; Akhunov, E.D.; Keller, B.; Wicker, T.; Kilian, B. Sequencing of chloroplast genomes from wheat, barley, rye and their relatives provides a detailed insight into the evolution of the Triticeae tribe. PLoS ONE 2014, 9, e85761. [CrossRef] [PubMed] 
40. Diekmann, K.; Hodkinson, T.R.; Wolfe, K.H.; van den Bekerom, R.; Dix, P.J.; Barth, S. Complete chloroplast genome sequence of a major allogamous forage species, perennial ryegrass (Lolium perenne L.). DNA Res. 2009, 16, 165-176. [CrossRef] [PubMed]

41. Corneille, S.; Lutz, K.; Maliga, P. Conservation of rna editing between rice and maize plastids: Are most editing events dispensable? Mol. Gen. Genet. MGG 2000, 264, 419-424. [CrossRef] [PubMed]

42. Calsa Júnior, T.; Carraro, D.M.; Benatti, M.R.; Barbosa, A.C.; Kitajima, J.P.; Carrer, H. Structural features and transcript-editing analysis of sugarcane (Saccharum officinarum L.) chloroplast genome. Curr. Genet. 2004, 46, 366-373. [CrossRef] [PubMed]

43. Song, W.; Henry, R.J. Molecular analysis of the DNA polymorphism of wild barley (Hordeum spontaneum) germplasm using the polymerase chain reaction. Genet. Resour. Crop Evol. 1995, 42, 273-280. [CrossRef]

44. Larkin, M.A.; Blackshields, G.; Brown, N.P.; Chenna, R.; McGettigan, P.A.; McWilliam, H.; Valentin, F.; Wallace, I.M.; Wilm, A.; Lopez, R.; et al. Clustal W and clustal X version 2.0. Bioinformatics 2007, 23, 2947-2948. [CrossRef] [PubMed]

45. Ruwe, H.; Castandet, B.; Schmitz-Linneweber, C.; Stern, D.B. Arabidopsis chloroplast quantitative editotype. FEBS Lett. 2013, 587, 1429-1433. [CrossRef] [PubMed]

46. Morton, R.B. The role of context-dependent mutations in generating compositional and codon usage bias in grass chloroplast DNA. J. Mol. Evol. 2003, 56, 616-629. [CrossRef] [PubMed]

47. Morton, R.B.; Oberholzer, M.V.; Clegg, T.M. The influence of specific neighboring bases on substitution bias in noncoding regions of the plant chloroplast genome. J. Mol. Evol. 1997, 45, 227-231. [CrossRef] [PubMed]

48. Tillich, M.; Lehwark, P.; Morton, B.R.; Maier, U.G. The evolution of chloroplast RNA editing. Mol. Biol. Evol. 2006, 23, 1912-1921. [CrossRef] [PubMed]

49. Grosche, C.; Funk, H.T.; Maier, U.G.; Zauner, S. The chloroplast genome of Pellia endiviifolia: Gene content, RNA-editing pattern, and the origin of chloroplast editing. Genome Biol. Evol. 2012, 4, 1349-1357. [CrossRef] [PubMed]

50. Kugita, M.; Yamamoto, Y.; Fujikawa, T.; Matsumoto, T.; Yoshinaga, K. RNA editing in hornwort chloroplasts makes more than half the genes functional. Nucleic Acids Res. 2003, 31, 2417-2423. [CrossRef] [PubMed]

51. Jiang, Y.; Fan, S.L.; Song, M.Z.; Yu, J.N.; Yu, S.X. Identification of rna editing sites in cotton (Gossypium hirsutum) chloroplasts and editing events that affect secondary and three-dimensional protein structures. Genet. Mol. Res. GMR 2012, 11, 987-1001. [CrossRef] [PubMed]

52. Du, P.; Li, Y. Prediction of C-to-U RNA editing sites in plant mitochondria using both biochemical and evolutionary information. J. Theor. Biol. 2008, 253, 579-586. [CrossRef] [PubMed]

53. Chen, H.; Deng, L.; Jiang, Y.; Lu, P.; Yu, J. RNA editing sites exist in protein-coding genes in the chloroplast genome of Cycas taitungensis. J. Integr. Plant Biol. 2011, 53, 961-970. [CrossRef] [PubMed]

54. Huang, Y.-Y.; Matzke, A.J.M.; Matzke, M. Complete sequence and comparative analysis of the chloroplast genome of coconut palm (Cocos nucifera). PLoS ONE 2013, 8, e74736. [CrossRef] [PubMed]

55. Timme, R.E.; Kuehl, J.V.; Boore, J.L.; Jansen, R.K. A comparative analysis of the Lactuca and Helianthus (Asteraceae) plastid genomes: Identification of divergent regions and categorization of shared repeats. Am. J. Bot. 2007, 94, 302-312. [CrossRef] [PubMed]

56. Zito, F.; Kuras, R.; Choquet, Y.; Kössel, H.; Wollman, F.-A. Mutations of cytochrome b6 in Chlamydomonas reinhardtii disclose the functional significance for a proline to leucine conversion by petB editing in maize and tobacco. Plant Mol. Biol. 1997, 33, 79-86. [CrossRef] [PubMed]

57. Maier, R.M.; Hoch, B.; Zeltz, P.; Kössel, H. Internal editing of the maize chloroplast ndha transcript restores codons for conserved amino acids. Plant Cell 1992, 4, 609-616. [CrossRef] [PubMed]

58. Karcher, D.; Bock, R. The amino acid sequence of a plastid protein is developmentally regulated by RNA editing. J. Biol. Chem. 2002, 277, 5570-5574. [CrossRef] [PubMed]

59. Maier, U.G.; Bozarth, A.; Funk, H.T.; Zauner, S.; Rensing, S.A.; Schmitz-Linneweber, C.; Börner, T.; Tillich, M. Complex chloroplast RNA metabolism: Just debugging the genetic programme? BMC Biol. 2008, 6, 1-9. [CrossRef] [PubMed]

(C) 2016 by the authors; licensee MDPI, Basel, Switzerland. This article is an open access article distributed under the terms and conditions of the Creative Commons Attribution (CC-BY) license (http:/ / creativecommons.org/licenses/by/4.0/). 